UDC 661.185

\title{
SYNTHESIS AND PROPERTIES OF NEW SURFACTANTS BASED ON COTTON-SEED OIL TRIGLYCERIDES, ETHANOLAMINES AND ORTOPHOSPHORIC ACID
}

\author{
I.A.Zarbaliyeva \\ Y.Mamedaliyev Institute of Petrochemical Processes, NAS of Azerbaijan \\ ilhamachem447@mail.ru
}

\begin{abstract}
Received 12.07.2017
By interaction of cotton-seed oil triglycerides with monoethanolamine monoethylolamide of cotton-seed oil acid fraction is obtained which is further phosphated by orthophosphoric acid. The obtained phosphate-derivative is reacted with mono-, di- and triethanolamine synthesizing respective ethanolamine complexes. The structure and composition of these complexes were identified by NMR $\left({ }^{1} \mathrm{H}\right.$ and $\left.{ }^{13} \mathrm{C}\right)$ and IR-spectroscopy methods. Some of the physico-chemical indices of the ethanolamine complexes have been determined. By stalagmometric measurements their high surface activity at the water-kerosene border has been shown. Laboratory tests revealed strong petroleum collecting and dispersing properties of these complexes that enable to remove thin petroleum films from the water surface.
\end{abstract}

Keywords: cotton-seed oil triglycerides, ethanolamines, monoethylolamide, monoethylolamide phosphate, etanolaminophosphate complexes, surfactants, petroleum collecting, dispersing.

Contamination of the World Ocean with petroleum is one of the most serious ecological problems standing before the mankind. Petroleum spills occurring due to various reasons lead to formation of thick slicks. Such petroleum slicks may be liquated using special mechanical devices. After such operations thin petroleum films inevitably remain on the water surface. These films may be removed only applying colloidal-chemical means which include usage of petroleum-collecting and petroleum-dispersing reagents [1-4]. Among such reagents which are surfactants, of a particular interests are reagents based on renewable and alternative raw materials. Here, first of all, vegetable oils should be mentioned which are harmless to environment and cheap [5-8]. In the present article considered new surfactants possessing petroleum-collecting and dispersing effectiveness were synthesized on the basis of cotton-seed oil which is an available raw material in our country also having a relatively low cost.

\section{Experimental}

Cotton-seed oil is a local commodity product. Among residues of saturated flatty acids in this oil triglycerides, miristic acid $\left(\mathrm{C}_{14}\right)$ constitutes $0.3-0.5 \%$, palmitic acid $\left(\mathrm{C}_{16}\right)-20.0$ $22.0 \%$, stearic acid $\left(\mathrm{C}_{18}\right)-2.0 \%$, arachinic acid $\left(\mathrm{C}_{20}\right)-0.1-0.6 \%$. From unsaturated fatty acids, residues of oleic acid $\left(\mathrm{C}_{18}\right)$ make up 30.5-35.2\% and those of linoleic acid $\left(\mathrm{C}_{18}\right)-41.7-44.0 \%$.

Monoethanolamine (MEA) was a reagent of "pure" grade produced by Olaynen Chemical Reagents Factory (Latvia).

Diethanolamine (DEA) was a product of "pure" analytical grade of "Merck" (Germany).

Triethanolamine (TEA) was from "Kazanorgsintez" Joint Stock Company (Russian Federation).

The above-mentioned thriethanolamines were used without any purification procedures.

Orthophophoric acid was used as $86 \%$ wt. aqueous solution produced by "ComponentReactant" Joint Stock Company (Russian Federation).

Water used as a bidistillate.

Surface activity of the synthesized surfactants was estimated at the water-kerosene border by stalagmometric method.

Specific electroconductivity $(x)$ of the surfactants aqueous solutions was measured by "Anion 4120" conductometer (Russian Federation).

NMR ${ }^{1} \mathrm{H}$ and $\mathrm{NMR}{ }^{13} \mathrm{C}$ spectra were registered by Bruker Advance II 300.13 (75.468 for ${ }^{13} \mathrm{C}$ ) spectrometer under room conditions.

IR spectra were recorded by Vertex 70 (Bruker) spectrometer in the range 4000-400 $\mathrm{cm}^{-1}$ using $\mathrm{KBr}$ pellets. 
Petroleum collecting and dispersing properties of the synthesized surfactants were studied by the following procedure both for purestate reagents and their $5 \mathrm{wt} \%$ aqueous solutions. In the laboratory tests, Ramana petroleum (density at $20^{\circ} \mathrm{C}-0.862 \mathrm{~g} / \mathrm{ml}$, kinematic viscosity at $20^{\circ} \mathrm{C}-16.80 \mathrm{cSt}$ ) was used. Into Petri dish, $40 \mathrm{ml}$ of petroleum is added. After formation of thin petroleum layer [thickness is $\sim(0.16-0.17) \mathrm{mm}] 0.02 \mathrm{~g}$ of surfactant (or its $5.0 \mathrm{wt} \%$ aqueous solution) is given onto the petroleum layer from the peripheral side. Petroleum-collecting coefficient is calculated according to the relationship $K=S_{0} / S$, where $S_{0}$ is the area of the petroleum layer surface prior to addition of a reagent whereas $S$ is a current area of the surface of petroleum spot formed under the action of the reagent. Time intervals $-\tau$ of measurements were also registered. The values of petroleum-collecting coefficient at different times enable to judge about dynamics of change of reagents impact.

\section{Results and discussion}

The reactions of obtaining monoethylolamide of cotton-seed oil acid fraction are conducted in an autoclave made of stainless steel and equipped with temperature-regulating system at $140-160^{\circ} \mathrm{C}$. This reaction is carried out without a solvent and a special catalyst at molar ratio of cotton-seed oil triglycerides and MEA equaling 1:3 monoethylolamide is formed according to this reaction scheme ( $\mathrm{R}$ is hydrocarbon radical of fatty acid) $[5,6]$ :<smiles>[R]C(=O)OCC(COC([R])=O)C([R])=O</smiles>

Phosphation of the obtained monoethylolamide with the purpose to increase its hydrophilicity is performed with participation of equimolar amount of ortophosphoric acid. This<smiles>[R]C(=O)NCCO</smiles><smiles>OCC(O)CO</smiles>

reaction is carried out in a thermostat at 50$60^{\circ} \mathrm{C}$ during 20-23 hours. The scheme of obtaining phosphate-derivative of monoethylolamide may be described as follows:

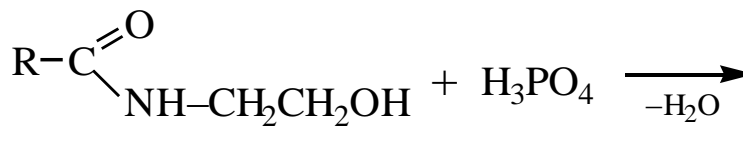

This reaction is accompanied with an increase of viscosity and colour darkening.

Then, to the obtained phosphate-derivative, ethanolamine (separately MEA, DEA and TEA) is added at equimolar ratio. Com-<smiles>[R]C(=O)NCCO[P+](=O)O</smiles>

plexation reaction is conducted at $50-60^{\circ} \mathrm{C}$ in a thermostat during 20 hours. Further increase of viscosity and colour darkening are observed. The scheme of complexation reactions may be written in such a form:<smiles>[R]C(=O)NCCOP(=O)(O)[NH2+][CH]COCCCCCCO</smiles>

where $x$ may be 0,1 or 2 . 
Table 1. Conditions of the complexation reaction and some physico-chemical indices of ethanolamine complexes of monoethylolamido-phosphate of cotton-seed oil acid fraction

\begin{tabular}{|c|c|c|c|c|c|c|}
\hline $\begin{array}{l}\text { Ethanol- } \\
\text { amine } \\
\text { complex }\end{array}$ & $\begin{array}{l}\text { Temperature } \\
\text { of synthesis, } \\
{ }^{0} \mathrm{C}\end{array}$ & $\begin{array}{c}\text { Duration at } \\
\text { of synthesis, } \\
\text { hour }\end{array}$ & $\begin{array}{c}\text { External } \\
\text { appearance }\end{array}$ & Solubility & $\begin{array}{c}\text { Amine } \\
\text { number, } \\
\text { mg HCl/g }\end{array}$ & $\begin{array}{l}\text { Specific elec- } \\
\text { troconductance, } \\
\mathrm{Ohm}^{-1} \mathrm{~m}^{-1}\end{array}$ \\
\hline MEA & $50-60$ & 20 & $\begin{array}{l}\text { dark-brown flowing } \\
\text { liquid }\end{array}$ & $\begin{array}{l}\text { soluble in water, ace- } \\
\text { tone, } \mathrm{CCl}_{4} \text {, benzene, } \\
\text { practically soluble in } \\
\text { isooctane and kero- } \\
\text { sene, } \\
\text { practically insoluble } \\
\text { in isopropanol }\end{array}$ & 0.23 & 0.007875 \\
\hline DEA & "-" & "-" & $\begin{array}{l}\text { brown-red, modera- } \\
\text { tely flowing liquid }\end{array}$ & "-" & 0.16 & 0.005250 \\
\hline TEA & "-" & "-" & brown-viscous liquid & "-" & 0.38 & 0.005325 \\
\hline
\end{tabular}

Identification of the synthesized complexes was made using NMR $\left({ }^{1} \mathrm{H}\right.$ and $\left.{ }^{13} \mathrm{C}\right)$ and IR spectroscopy methods. In Figure $1 a$, spectrum ${ }^{1} \mathrm{H}$ NMR and in Figure $1 b$, spectrum ${ }^{13} \mathrm{C}$ NMR of TEA complex are depicted.

In spectrum ${ }^{1} \mathrm{H}$ NMR, there are proton resonance signals of $\mathrm{CH}_{3}$-group at $0.80 \mathrm{ppm}$, $\mathrm{CH}_{2}$-group at $1.20 \mathrm{ppm}, \mathrm{CH}_{2} \mathrm{C}(\mathrm{O})$ group at $1.50 \mathrm{ppm}, \mathrm{OCH}_{2}$-group at $1.85-2.30 \mathrm{ppm}, \mathrm{NCH}_{2}-$ group at 2.60-2.80 ppm, double bond at 3.10$3.60 \mathrm{ppm}, \mathrm{C}-\mathrm{OH}$ group at $5.25 \mathrm{ppm}$ and $\mathrm{P}-\mathrm{OH}$ group at $7.60 \mathrm{ppm}$.

At spectrum NMR ${ }^{13} \mathrm{C}$ (Figure $1 b$ ), carbon-atom resonance signals are recorded at 13.5-41.4 ppm for carboxylic acids backbone carbons, $60.0 \mathrm{ppm}$ for $\mathrm{OCH}_{2}$ carbon, 127.0 129.0 ppm for $\mathrm{CH}_{2}-\mathrm{NH}$ and $\mathrm{CH}_{2} \mathrm{~N}$ groups carbons, $174.0 \mathrm{ppm}$ for $\mathrm{C}(\mathrm{O}) \mathrm{N}$ group carbon atom.

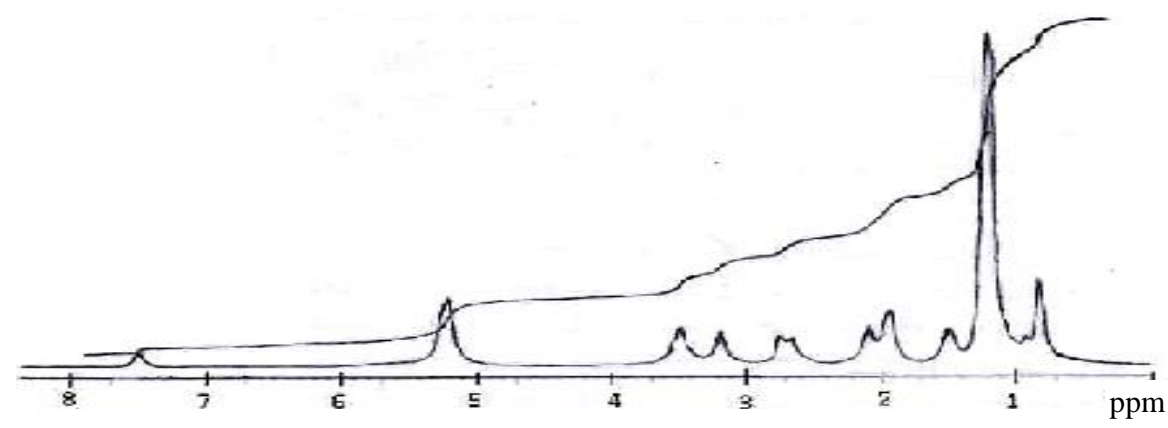

Fig.1a. Spectrum ${ }^{1}$ H NMR of TEA complex of monoethylolamidophosphate of cotton-seed oil acid fraction.
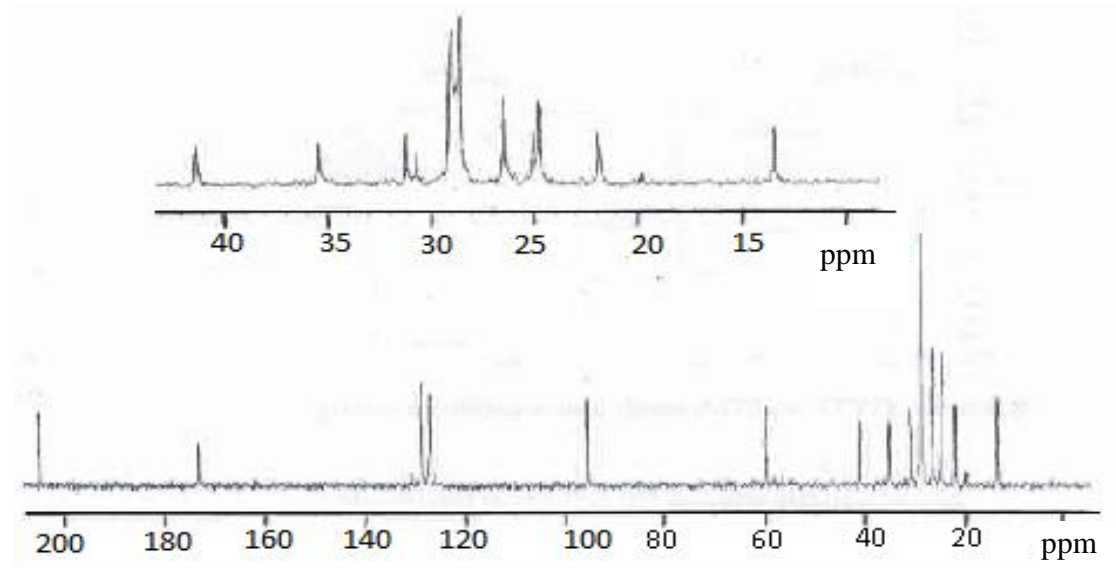

Fig.1b. Spectrum NMR ${ }^{13} \mathrm{C}$ of TEA complex of monoethylolamidophosphate of cotton-seed oil acid fraction. 
In IR spectrum of TEA complex (Figure 2), the following absorbtion bands are observed: $\mathrm{OH}-$ valent and $\mathrm{N}-\mathrm{H}$ valent vibration at 3299 $\mathrm{cm}^{-1}, \mathrm{C}-\mathrm{H}$ of double fond $3011 \mathrm{~cm}^{-1}, \mathrm{C}-\mathrm{H}$ saturated valent -2918 and $2850 \mathrm{~cm}^{-1}, \mathrm{NC}=\mathrm{O}$ valent vibration - $1644 \mathrm{~cm}^{-1}, \mathrm{~N}-\mathrm{H}$ deformational $1556 \mathrm{~cm}^{-1}, \mathrm{C}-\mathrm{H}$ deformational -1465 and 1377 $\mathrm{cm}^{-1}, \mathrm{C}-\mathrm{N}$ valent $-1215 \mathrm{~cm}^{-1}, \mathrm{C}-\mathrm{O}$ valent in $\mathrm{C}-\mathrm{OH}$ fragment $-1057 \mathrm{~cm}^{-1}, \mathrm{P}-\mathrm{O}$ valent $1039 \mathrm{~cm}^{-1}$ and $\left(\mathrm{CH}_{2}\right)_{x}$ "pendulum" vibrations $719 \mathrm{~cm}^{-1}$.

Surface activity of the synthesized complexes has been studied at the water-kerosene border by stalagmometric method. The results of stalagmometric measurements have been included into Table 2.

As is seen from the obtained results, all three complexes exhibit surface activity at the indicated border. The most active one is MEA complex which decreases the interfacial tension from 46.0 down to $2.1 \mathrm{mN} / \mathrm{m}$ (at $5 \%$ concentra- tion). The least active is TEA complex (9.2 $\mathrm{mN} / \mathrm{m}$ at the same concentration).

The results of laboratory tests of the synthesized complexes on petroleum-collecting and petroleum-dispersing capacities have been presented in Table 3.

These results show that the synthesized complexes manifest high petroleum-collecting and petroleium-dispersing capacities. Thus, for $5 \%$ aqueous solution of MEA complex, the duration of the reagent action in fresh water is longer than 13 days, the value of $K$ being 42.6. In the sea water, this solution is a strong dispersant ( $\tau>13$ days). 5\% aqueous solution of DEA complex demonstrates good dispersing properties both in fresh and sea waters $(\tau>13$ days). 5\% aqueous solution of TEA complex shows a mixed (petroleum-dispersing-collecting) capability in fresh water $\left(K_{\max }=28.6, \tau>13\right.$ days) and purely dispersing properties in the sea water ( $\tau \sim 10$ days).

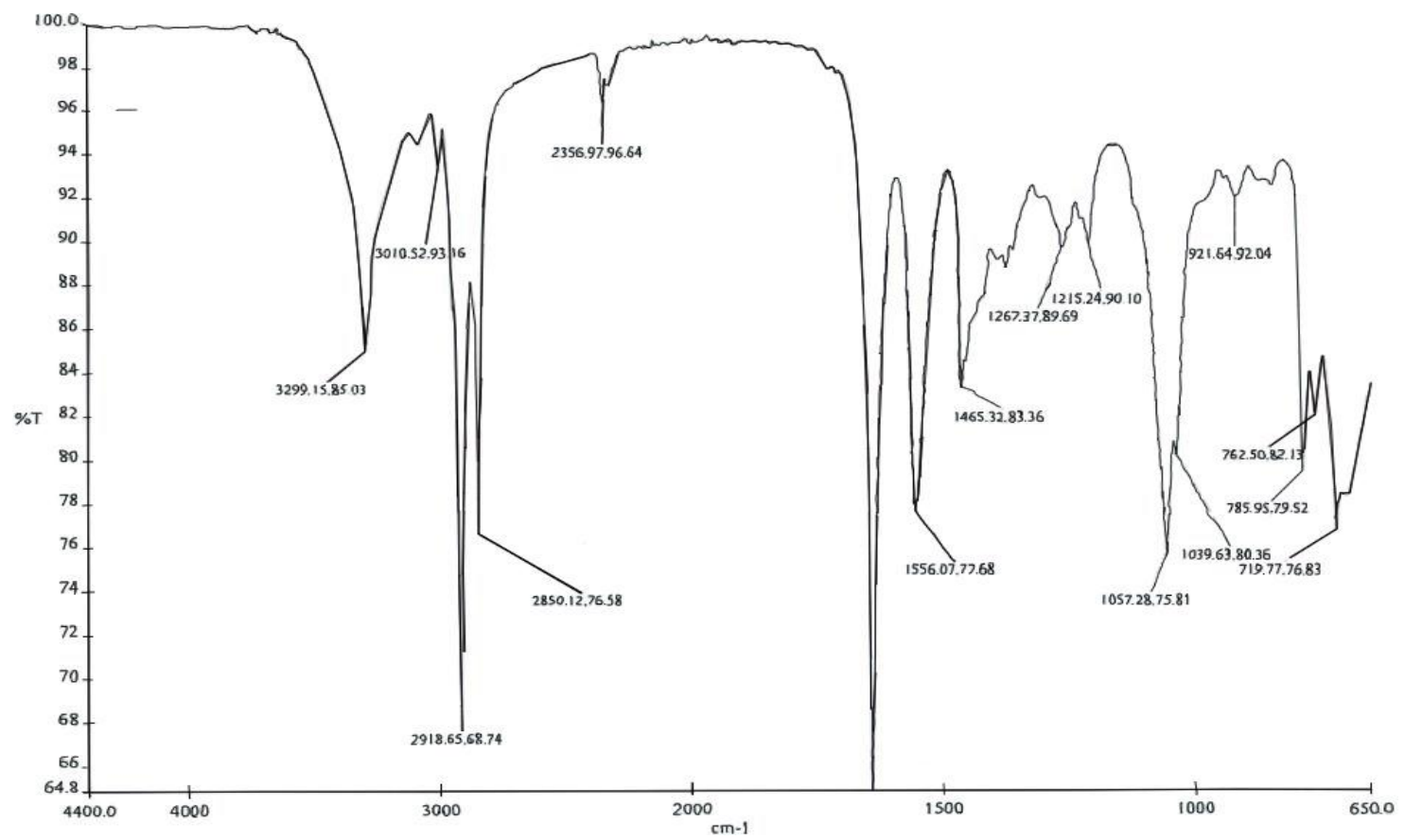

Fig.2. IR spectrum of TEA complex of monoethylolamidophosphate of cotton-seed oil acid fraction.

Table 2. Results of stalagmometric studies of surface activity of ethanolamine complexes of monoethylolamidophosphate of cotton-seed oil acid fraction at the water-kerosene border $\left(21^{\circ} \mathrm{C}\right)$

\begin{tabular}{|l|c|c|c|c|c|c|}
\hline \multirow{2}{*}{ Reagent } & \multirow{2}{*}{$\begin{array}{c}\text { Solvent of } \\
\text { reagent }\end{array}$} & \multicolumn{5}{|c|}{ Concentration of reagent, wt \% } \\
\cline { 3 - 7 } & & 0.025 & 0.050 & 1.000 & 3.000 & 5.000 \\
\hline MEA complex & Water & 4.8 & 7.1 & 2.5 & 4.2 & 2.1 \\
\hline DEA complex & "-" & 2.8 & 7.3 & 11.4 & 8.5 & 3.5 \\
\hline TEA complex & "-" & 7.8 & 8.5 & 21.8 & 12.1 & 9.2 \\
\hline
\end{tabular}


Table 3. Results of studies of petroleum-collecting and petroleum-dispersing properties of ethanolamine complexes of monoethylolamidophosphate of cotton-seed oil acid fraction; Ramana petroleum

\begin{tabular}{|c|c|c|c|c|c|}
\hline \multicolumn{2}{|c|}{ Distilled water } & \multicolumn{2}{|c|}{ Fresh water } & \multicolumn{2}{|c|}{ Caspian sea water } \\
\hline$\tau$, hours & $K$ & $\tau$, hours & $K$ & $\tau$, hours & $K$ \\
\hline \multicolumn{6}{|c|}{5 wt. \% aqueous solution of MEA complex } \\
\hline $\begin{array}{c}0 \\
3.33-198.00\end{array}$ & $\begin{array}{l}39.00 \\
\text { Disp. }\end{array}$ & $\begin{array}{c}0-24.5 \\
123.5-320.00\end{array}$ & $\begin{array}{l}42.6 \\
\text { Disp. }\end{array}$ & $0-320.00$ & Disp \\
\hline \multicolumn{6}{|c|}{ Pure-state MEA complex } \\
\hline $\begin{array}{c}0-3.33 \\
24.5-123.50 \\
199.5-320.0\end{array}$ & $\begin{array}{l}36.12 \\
37.20 \\
32.60 \\
\end{array}$ & $\begin{array}{c}0-118.00 \\
123.5\end{array}$ & $\begin{array}{l}\text { Disp. } \\
\text { Dag }\end{array}$ & $\begin{array}{c}0-204.00 \\
320.00\end{array}$ & $\begin{array}{l}\text { Disp } \\
\text { Disp }\end{array}$ \\
\hline \multicolumn{6}{|c|}{5 wt. \% aqueous solution of DEA complex } \\
\hline $\begin{array}{c}0-3.33 \\
24.5-320.50\end{array}$ & $\begin{array}{l}36.20 \\
\text { Disp. }\end{array}$ & $\begin{array}{c}0-118.00 \\
320.00 \\
\end{array}$ & $\begin{array}{c}\text { Disp. } \\
\text { Spilled }\end{array}$ & $0-392.00$ & Disp. \\
\hline \multicolumn{6}{|c|}{ Pure-state DEA complex } \\
\hline $\begin{array}{c}0-123.00 \\
128.5-320.50 \\
\end{array}$ & $\begin{array}{l}26.80 \\
\text { Disp. }\end{array}$ & $0-248.00$ & Disp. & $\begin{array}{c}0-123.00 \\
148.00 \\
\end{array}$ & $\begin{array}{l}\text { Disp. } \\
\text { Spilled }\end{array}$ \\
\hline \multicolumn{6}{|c|}{5 wt. \% aqueous solution of TEA complex } \\
\hline $0-320.00$ & Disp. & $\begin{array}{c}0-3.33 \\
24.50-48.50 \\
62.45-392.00 \\
\end{array}$ & $\begin{array}{l}28.60 \\
\text { Disp. } \\
8.70\end{array}$ & $0-392.00$ & Disp. \\
\hline \multicolumn{6}{|c|}{ Pure-state TEA complex } \\
\hline $\begin{array}{c}0-3.33 \\
23.50-264.00\end{array}$ & $\begin{array}{l}32.60 \\
36.60\end{array}$ & $\begin{array}{c}0 \\
3.33-320.00\end{array}$ & $\begin{array}{l}\text { Disp. } \\
22.78\end{array}$ & $\begin{array}{c}0-234.00 \\
248.00\end{array}$ & $\begin{array}{l}\text { Disp. } \\
\text { Spilled }\end{array}$ \\
\hline
\end{tabular}

Thus, it has been established that phosphation of monoethylolamide of cotton-seed oil acid fraction and further complexation of the phosphate with MEA, DEA and TEA enable to obtain ethanolamine complexes which have a high surface activity at the water-kerosene border and possess strong petrocollecting and petrodispersing properties that make possible to use them for removing thin oil films from the water surface.

\section{References}

1. Rustamov M.I. Abbasov V.M. Mamedova T.A. Piriev N.N. Ekologicheskie problemy Zemli i alternativnye istochniki energii. Baku: Elm, 2008. $717 \mathrm{~s}$.

2. Abbasov V.M. Ekologicheskie problemy Kaspiia, sviazannye s dobychei i transportirovkoi nefti // Protcessy neftehimii i neftepererabotki. 2002. 4(11). S. 6-10.

3. Gumbatov G.G., Dashdiev R.A. Primenenie PAV dlia likvidatcii avariinykh razlivov nefti na vodnoi poverkhnosti. Baku: Elm, 1998. $210 \mathrm{~s}$.

4. Humbatov H.H., Dashdiyev R.A., Asadov Z.H., Askerov F.S., Hasanov A.I. Chemical reagents and petroleum production. Baku: Elm, 2001. 448 p.
5. Zərbəliyeva İ.A., Әsədov Z.H., Rəhimov R.A. Ali alifatik monokarbon turşuları və onların fraksiyalarının etilolamidlərinin təbii triqliseridlərdən alınması, tədqiqi və tətbiqi // Az. Texn. Un-ti. Elmi əsərlər. Fundamental Elmlər. 2015. № 2. S. 211-219.

6. Asadov Z.H., Rahimov R.A., Salamova N.V., Zarbaliyeva I.A., Ahmadova G.A. Green synthesis of surfactants for removing crude oil films off water surface / International Oil Spill Conference Proceedings: May 2014. No 1. P. 299-689.

7. Asadov Z.H., Zarbaliyeva I.A., Rahimov R.A., Salamova N.V., Eyyubova S.K., Ahmadova G.A., Asadova A.Z. Petroleum-collecting and dispersing chemicals for cleaning sea surface from thin petroleum slicks // Bull. Chem. Soc. Ethiop. 2014. V. 28. No 2. P. 205-214.

8. Asadov Z.H., Zarbaliyeva I.A., Ahmadova G.A., Rahimov R.A., Mammadova Kh.A. Obtaining of new surfactants based on acid fraction of tall oil // Processes of petrochemistry and oil refining. 2010. V. 11. No 1(41). P. 147-153.

9. Asadov Z.G., Ragimov R.A., Salamova N.V., Akhmedova G.A., Zarbalieva I.A. Novye neftesobiraiushchie i dispergiruiushchie reagenty na osnove etanolaminov, ortofosfornoi kisloty, kukuruznogo i olivkovogo masel // "Neftepererabotka, neftehimiia, kataliz" (sb. Tr. INKHP NANA). Baku: Elm, 2010. C. 107-120. 


\section{PAMBIQ YAĞI TRIQQLISERIDLӘRİ, ETANOLAMINLOR Və ORTOFOSFAT TURŞUSU ӘSASINDA YENI SəTHI-AKTIV MADDӘLӘRIN SINTEZI VӘ XASSəLəRI}

\section{İ.A.Zərbəliyeva}

Pambıq yağı triqliseridlərinin monoetanolaminlə qarşılıqlı təsirindən pambıq yağı turşu fraksiyasının monoetilolamidi alınmış və ortofosfat turşusu ilə fosfatlaşdırılmışdır. Bu fosfat törəməsinin sonradan mono-, di- və trietanolaminlə reaksiyalarından müvafiq etanolamin kompleksləri sintez edilmişdir. Alınmış komplekslərin quruluşu və tərkibi NMR $\left({ }^{1} \mathrm{H}\right.$ və $\left.{ }^{13} \mathrm{C}\right)$ və İQ spektroskopiya üsulları ilə təsdiqlənmişdir. Etanolamin komplekslərinin bəzi fiziki-kimyəvi göstəriciləri təyin edilmiş, stalaqmometrik üsulla onların su-kerosin sərhədində yüksək səthi aktivliyə malik olduğu göstərilmişdir. Laboratoriya sınaqları nəticəsində müəyyən edilmişdir ki, bu komplekslər qüvvətli neftyığıcılıq və neftdispersləmə xassələrinə malikdir. Bu onların tətbiqi ilə su səthindən nazik neft təbəqələrini kənar etməyə imkan verir.

Açar sözlor: pambıq yağı triqliseridlari, etanolaminlar, monoetilolamid, monoetilolamidofosfat, etanolaminofosfat komplekslori, sathi aktivlik, neftylğma, neftdisperslamə

\section{СИНТЕЗ И СВОЙСТВА НОВЫХ ПОВЕРХНОСТНО-АКТИВНЫХ ВЕЩЕСТВ НА ОСНОВЕ ТРИГЛИЦЕРИДОВ ХЛОПКОВОГО МАСЛА, ЭТАНОЛАМИНОВ И ОРТОФОСФОРНОЙ КИСЛОТЫ}

\section{И.А.Зарбалиева}

Взаимодействием триглицеридов хлопкового масла с моноэтаноламином получен моноэтилоламид кислотной фракции хлопкового масла, который далее фосфатирован ортофосфорной кислотой. Реакцией конечного фосфата с моно-, ди- и триэтаноламином синтезированы соответствующие этаноламинные комплексы. Строение и состав полученных комплексов подтверждены методами ЯМР $\left({ }^{1} \mathrm{H}\right.$ и $\left.{ }^{13} \mathrm{C}\right)$ и ИК-спектроскопии. Определены некоторые физико-химические показатели этих комплексов, сталагмометрическим методом показана их высокая поверхностная активность на границе вода-керосин. В результате лабораторных испытаний установлено, что синтезированные комплексы обладают сильными нефтесобирающими и нефтедиспергирующими свойствами. Это позволяет с их помощью удалять тонкие пленки с водной поверхности.

Ключевые слова: триглицериды хлопкового масла, этаноламины, моноэтилоламид, моноэтилоламидофосфат, этаноламинофосфатные комплексы, поверхностная активность, нефтесобирание, нефтедиспергирование 